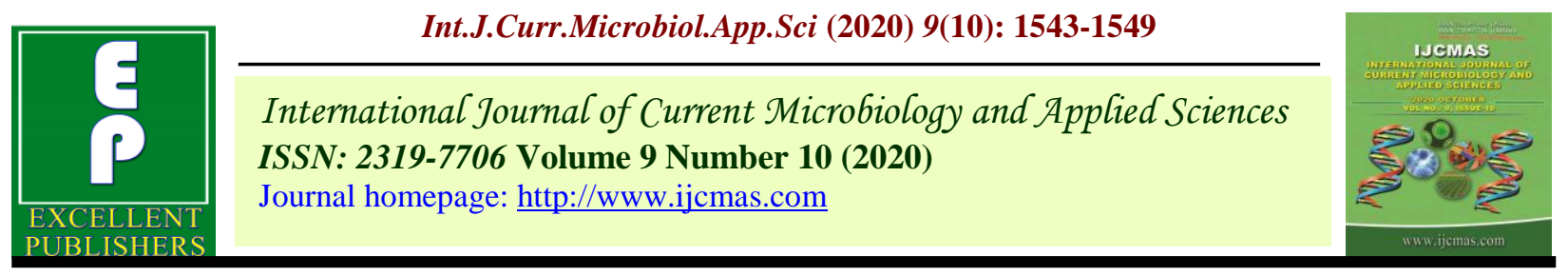

Original Research Article

https://doi.org/10.20546/ijcmas.2020.910.184

\title{
Survivality and Growth of Fry of Indian Major Carps Reared in Treated Effluents of PSPD, Bhadrachalam
}

\author{
T. Suguna* \\ Fisheries Research Station, S.V. Veterinary University, \\ West Godavari, Andhra Pradesh, India \\ *Corresponding author
}

\begin{abstract}
A B S T R A C T
\end{abstract}

\begin{tabular}{l} 
Key w o r d s \\
Indian Major carps, \\
Growth, \\
Survivality, \\
Godavari water, \\
Treated effluents, \\
PSPD \\
Bhadrachalam, \\
Impact assessment \\
\hline $\begin{array}{l}\text { Article Info } \\
\text { Accepted: } \\
\text { 12 September } 2020 \\
\text { Available Online: } \\
10 \text { October } 2020\end{array}$ \\
\hline
\end{tabular}

\section{Introduction}

Industrial untreated waste water represents a heavy source of environmental pollution. It effects both the water quality as well as the microbial and aquatic flora. Industrial effluents are characterized by their abnormal water quality. Process water in paper and board mills contains a lot of sugars and lignocelluloses, which support the growth of bacteria, mold and some yeast. Effluents from fertilizer plants contain a higher concentration
ITC paper boards and speciality papers division located at Sarapaka, Bhadrachalam, Khammam, Telangana is among the leading names in the business worldwide and largest manufacturer of paper, paper boards and bleached pulp in south Asia. The waste water generated in the process is treated chemically and biologically before discharge for irrigation. The survivality and growth of fry of Indian major carps (Catla catla, Labeo rohita and Cirihhinus mrigala) reared in treated effluents of PSPD, Bhadrachalam is evaluated. Fry are stocked in the ratio of 1:4:2 @ 3000/acre and fed with mixture of rice bran and groundnut cake. A significant enhancement in survivality and growth performance was noticed in the treated effluents, exhibiting their nutritive nature. Comparatively the growth rate of catla is higher due to abundance of zooplankton which is its choice food. Water quality parameters of treated effluents were conducive for fish rearing. 
Industrialization is the index of modernization, which leads to alteration in the physical, chemical and biological properties of environment. Waste water from industries has been tried by several researchers for irrigation. Irrigation of paper mills effluents has shown encouraging results on Oats and Orchard grass (Hashimoto and Yokato, 1965) on paddy, wheat and groundnut (Khambatta and Ketkar, 1969) Hansen et al., (1980) observed that irrigation with effluent is superior than the freshwater in respect of yield of sugarcane and plant characters. Whereas Somashekar et al., (1984) stated that the effluents not only contain nutrients that enhance the growth of crop plant but also have other toxic materials that reduces crop growth and have inhibiting soil characteristics.

Carp culture is contributing it's lion's share in freshwater fish production (J.K. Jena and Das, P.C. 2007) and meeting the demand of ever encouraging population. Pokhrel et al., (2004) stated that the pulp and paper production generates significantly large amounts of pollutants characterized by high concentration of suspended solids, chemical oxygen demand, toxicity and biological oxygen demand. The pollutants discharge from the paper industry affects aquatic and land ecosystems. Many studies reported toxic affects of untreated effluents of pulp and paper industrial waste waters (Schnell, A., Munkihrick, K.R. and Haley et al., 1985). Industries play important role in economic development of the country, if their waste water was treated appropriately, can be used for fish culture (Ujjania, N.C. et al., 2018).

In view of the conflicts on impact of effluents, a study was carried out on the treated effluents of Paperboard and Speciality Paper Division (PSPD), Bhadrachalam, Telangana to assess the suitability of the effluents on the earlier stages i.e. fry of Indian major carps.

\section{Materials and Methods}

Fry of $2.5 \mathrm{~cm}$ and 0.8 gms were stocked at the rate of 3000 / acre in Godavari water (control) and treated effluents in ponds at PSPD, ITC, Bhadrachalamin in the ratio of $1: 4: 2$ and reared for three months.

Depth of water was maintained $0.75-1.0 \mathrm{~m}$. Fertilization of ponds (0.085 ha) was not done. Mixture of rice bran and ground nut in $1: 1.5$ ratio is served as feed, as per the body weight @ 8-10\%,6-8\% and 4-6\% in due monthly course, respectively.

The elemental analysis and water quality parameters of the treated effluents are done by standard methods as per the Manuel of MITCON, 2003, Shinde et al., 1997and recorded regularly. The qualitative plankton analysis and growth performance are recorded fortnightly. The rate of survivality are recorded periodically. The fingerlings are Harvested after 3 months.

\section{Results and Discussion}

The fry of the Indian major carps reared in treated effluents were healthy without any sign of mortality and infection. The analytical results such as physico chemical, biological and elemental analysis of the treated effluents are as follows:

Comparatively the color of effluent was dark brown and smelling like rotten egg / sulphurous (Fig. 1, 2, 3). The $\mathrm{pH}$ of effluent ranged from 7.2 - 8.1.The effluent was slightly alkaline with TDS and Sulphate contents. The remaining parameters were present in optimum levels (Table 1). The elements, $\mathrm{Na}, \mathrm{K}, \mathrm{Ca}, \mathrm{Mg}$, and $\mathrm{Mn}$ were in lower concentrations where as, heavy metals like $\mathrm{Cd}, \mathrm{Pb}, \mathrm{Ni}, \mathrm{Hg}, \mathrm{Cr}, \mathrm{Co}$ and $\mathrm{Ag}$ were not detectable (Table 2). 
Table.1 Physico chemical analysis of PSPD treated effluents

\begin{tabular}{|c|c|c|}
\hline Sl. No. & Factor & Values \\
\hline 1. & Colour & Dark brown \\
\hline 2. & Odour & Sulphurous / smelling like rotten egg. \\
\hline 3. & Temperature ${ }^{\circ} \mathrm{C}$ & $24-36^{\circ} \mathrm{C}$ \\
\hline 4. & $\mathrm{pH}$ & $7.2-8.2$ \\
\hline 5. & Conductivity $\left(\mathrm{dsm}^{-1} / \mathrm{cm}\right)$ & 2.1 \\
\hline 6. & Alkalinity $\left(\mathrm{mg} \mathrm{L}^{-1}\right)$ & 256 \\
\hline 7. & Total hardness $\left(\mathrm{mg} \mathrm{L}^{-1}\right)$ & 352 \\
\hline 8. & Total suspended solids $\left(\mathrm{mg} \mathrm{L}^{-1}\right)$ & 81 \\
\hline 9. & Total Dissolved solids $\left(\mathrm{Mg} \mathrm{L}^{-1}\right)$ & 1052 \\
\hline 10. & Dissolved Oxygen $\left(\mathrm{Mg}^{-1}\right)$ & $1.9-4.5$ \\
\hline 11. & $\mathrm{COD}\left(\mathrm{Mg} \mathrm{L}^{-1}\right)$ & 152 \\
\hline 12. & $\mathrm{BOD}\left(\mathrm{Mg} \mathrm{L}^{-1}\right)$ & 23 \\
\hline 13. & Chlorides as $\mathrm{CL}\left(\mathrm{Mg} \mathrm{L}^{-1}\right)$ & 158 \\
\hline 14. & Sulphates as $\mathrm{So}_{4}\left(\mathrm{Mg} \mathrm{L}^{-1}\right)$ & 580 \\
\hline 15. & Phosphorous $\left(\mathrm{Mg} \mathrm{L}^{-1}\right)$ & 1.8 \\
\hline
\end{tabular}

Table.2 Elemental analysis of PSPD treated effluents

\begin{tabular}{|c|c|c|}
\hline Sl. No. & Element & Concentrations $\left(\mathbf{M g ~ M L}^{-\mathbf{1}}\right)$ \\
\hline $\mathbf{1 .}$ & $\mathrm{K}$ & 23.81 \\
\hline $\mathbf{2 .}$ & $\mathrm{Ca}$ & 127.05 \\
\hline $\mathbf{3}$ & $\mathrm{Mg}$ & 21.53 \\
\hline $\mathbf{4 .}$ & $\mathrm{Fe}$ & 1.14 \\
\hline $\mathbf{5}$. & $\mathrm{Mn}$ & 0.19 \\
\hline $\mathbf{6 .}$ & $\mathrm{Zn}$ & 0.37 \\
\hline $\mathbf{7 .}$ & $\mathrm{Cu}$ & 0.14 \\
\hline $\mathbf{8}$ & $\mathrm{Na}$ & 175.3 \\
\hline $\mathbf{9}$ & $\mathrm{Cd}$ & $\mathrm{ND}$ \\
\hline $\mathbf{1 0 .}$ & $\mathrm{Pb}$ & $\mathrm{ND}$ \\
\hline $\mathbf{1 1}$ & $\mathrm{Ni}$ & $\mathrm{ND}$ \\
\hline $\mathbf{1 2}$ & $\mathrm{Hg}$ & $\mathrm{ND}$ \\
\hline $\mathbf{1 3}$ & $\mathrm{Cr}$ & $\mathrm{ND}$ \\
\hline $\mathbf{1 4}$ & $\mathrm{Co}$ & $\mathrm{ND}$ \\
\hline $\mathbf{1 5}$ & $\mathrm{Ag}$ & $\mathrm{ND}$ \\
\hline
\end{tabular}

Table.3 Biological analysis of PSPD treated effluents

\begin{tabular}{|c|l|l|}
\hline Sl. No. & \multicolumn{1}{|c|}{ Plankton } & \multicolumn{1}{c|}{ Zooplankton } \\
\hline 1. & Diatoms & Protozoa - Feeble in number \\
\hline 2. & Blue green algae & Rotifers - appreciateable in number \\
\hline 3. & Green algae & $\begin{array}{l}\text { Cladocerens - extra ordinary rise in } \\
\text { population of moina. }\end{array}$ \\
\hline $\mathbf{4 .}$ & Euglenoids & Copepods - Fairly good \\
\hline
\end{tabular}


Fig.1 Effluent water

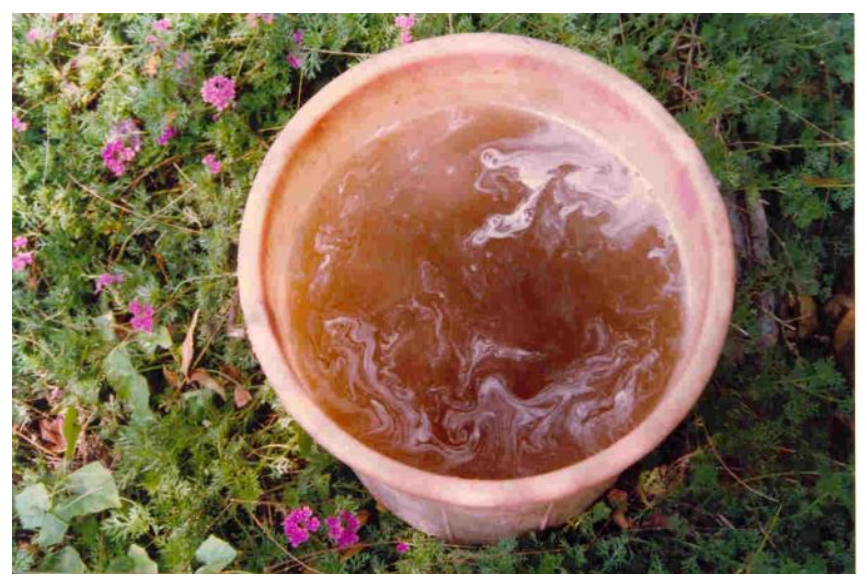

Fig.2 Experimental ponds

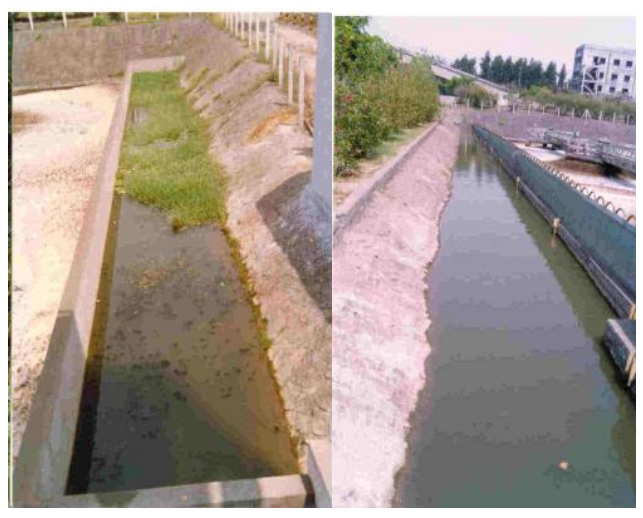

Fig.3 Fry of IMC for stocking

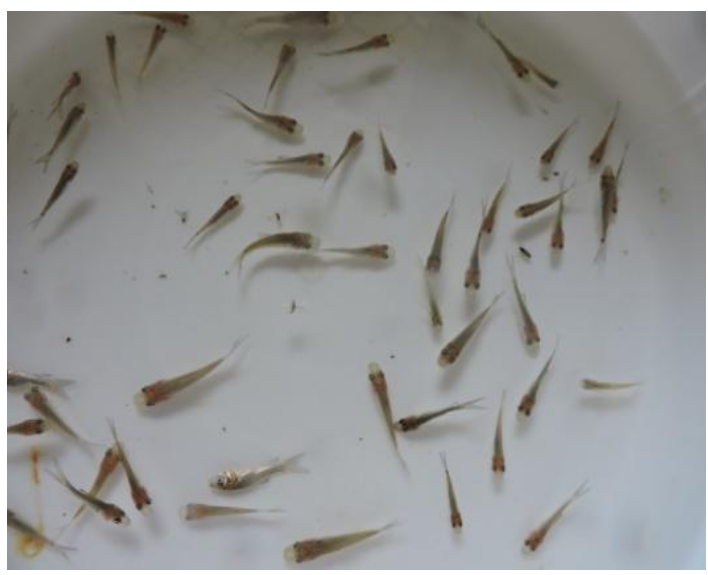


Fig.4 Rate of survivality

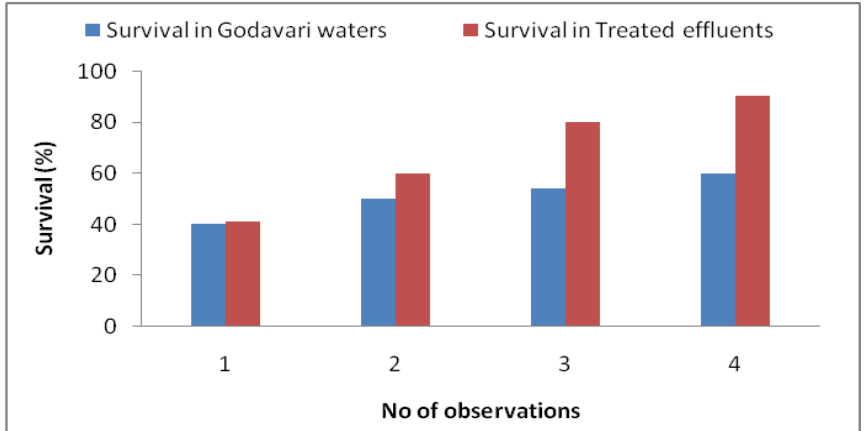

Fig.5a Growth performance: Variance in length

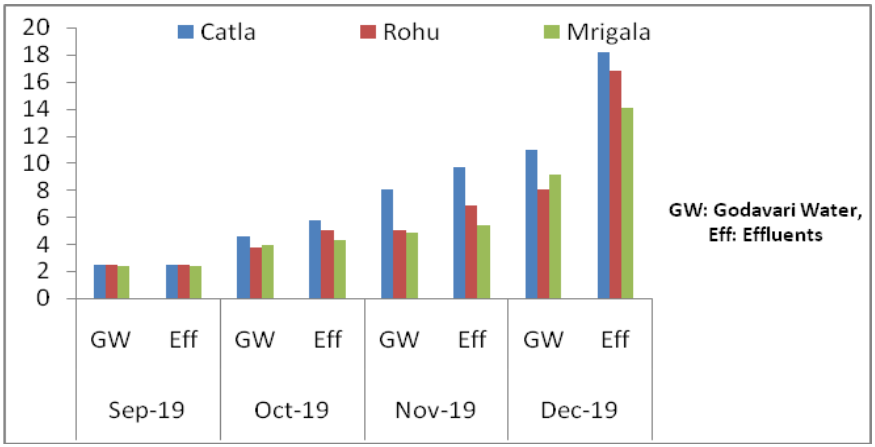

Fig.5b Growth performance: Variance in weight

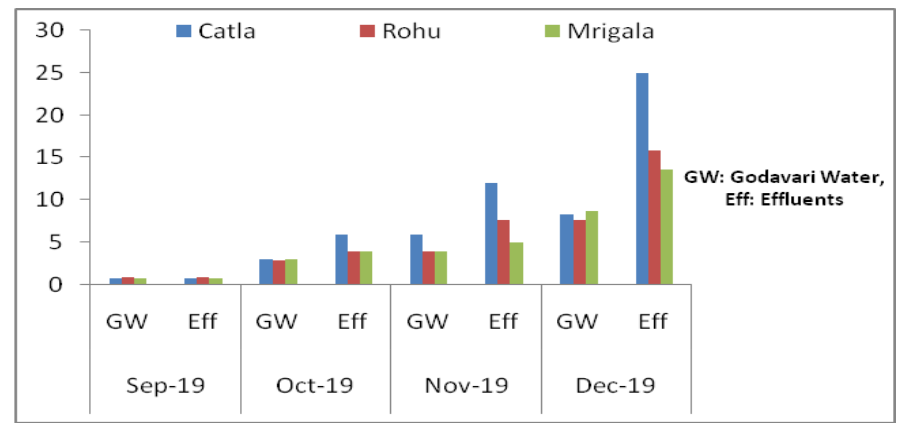

Fig.6 Harvested fingerlings (control)

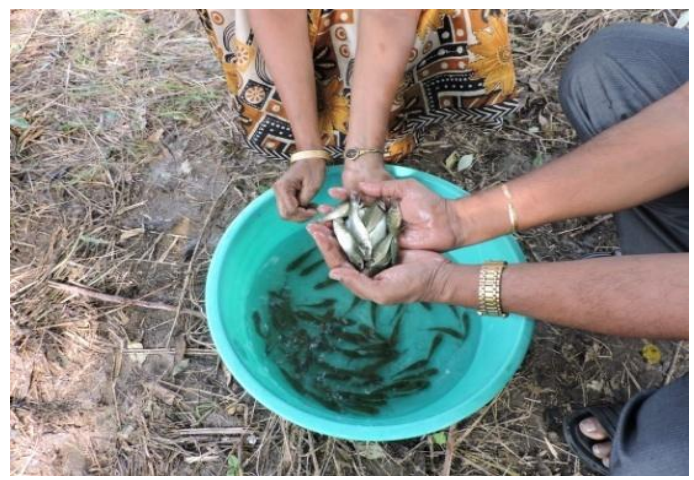


Fig.7 Harvested fingerlings (effluents)

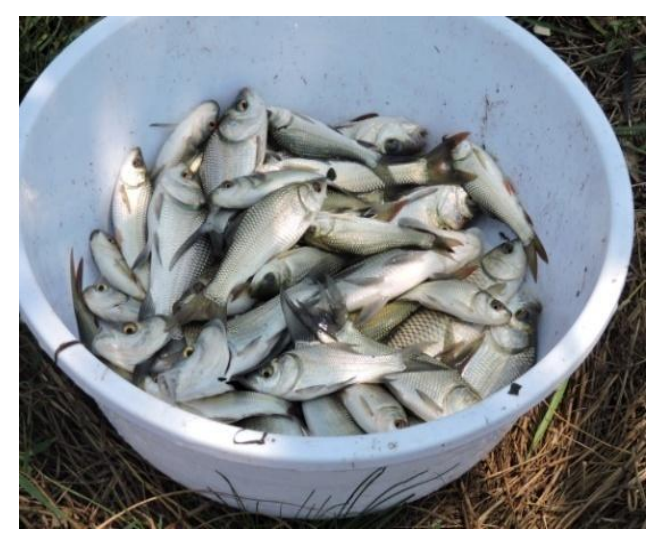

Blue green algae and green algae are predominantly seen in phytoplankton, whereas the Cladocerans, Copepodes and Rotifers are dominating in zooplankton (Table 3). The surviality (Fig. 4) and growth performance of fry reared in effluents are higher (Fig. 5a, 5b and 7) than that reared in Godavari waters / control (Fig. 5a, 5b and 6). The data of various parameters are coinciding with earlier findings of Ujjania et al., (2018) which reported of higher growth of carps reared in treated waste water of petro chemical industry.

In view of the encouraging results obtained, it infers that the plankton (phytoplankton and zooplankton) are fairly high in treated effluents which speaks of possible use of effluents as important resource for rearing of fish, as effluents are providing live fish food organisms. It is needless to mention that plankton are the choice fish food organisms.

Hence it can be concluded that the treated effluents from PSPD, Bhadrachalam, industry are nutritious and encouraged the growth of the fry of Indian major carps.

\section{References}

Haley, K.R., Hall, J.T., Bousquent, M.T. 1995. Effects of biologically treated bleached kraft mill effluent before and after mill conversa to increased chlorine dioxide substitution. Results of an experimental streams study. Envison. Toxicol. Chem., 14: 287-298.

Hansen, E.A., D.H. Dawson and D.N. Tolsted, 1980. Irrigation of intensively cultured plantations with paper mill effluent. Tappi, 63: 139-143.

Hashimoto and Yokoto, 1965: Edaphological studies on the utilization of waster pulp liquor. J. Sci. Soil Menura, Tokyo, 36: $231-234$.

Jena, J.K. and Das, P.C., 2007. ICAR journal of Indian Farming Vol. 56, No. 10, 19 22.

Khasambatta, S.J. and Ketkar, C.M., 1969. Present scheme for treatment and utilization of paper mill effluent on land for irrigation. Presented in symposium of problems connected with disposal of waste from various industries round about Poona Nov. 2930, 1969.

Munkittricj, K. R., Servos, M.R., Carey, J.H., Van Dar Kreek, G. 1997. J. Environmental impacts of pulp and paper waste water evidence for a reduction in environmental effects at north American pulp mills since. Water Sci. Technol, 35: 329-338.

Pokhral, D., Viraraghavan, T. 2004. Treatment of pulp and paper mill waste water 0 Review Sci. Total 
Envision, 333: 37-58.

Schnell, A., Hodson, P.V., Steel, P., Melcer, H., Carey, J.H. 2000. Enhanced biological treatment of bleached kraft mill effluents II. Reduction of mixed function oxygenase (MFO) induction in fish. Water Res. 34: $501-509$.

Shinde, D.D., D.G. Thorat, P.S. Gunjal and S.R. Kuchekar (1997). Physico Chemical aspects of pollution in Godavari River at Nasik. I. Aqua, Biol, 12 (1 \& 2) 85.
Somasekhar, R.K., M.T.G. Gowda, S.L.N. Shettigar and K.P. Srinath, 1984, The effect of industrial effluents on crop plants. Indian J. Environ Hlth., 26: 136-146.

Ujjania, N.C., Pankaj Gadhie, Ekhalak Ansari, M. Gadhie, 2018. Growth of Indian major carps reared in treated waste water of petrochemical industry. International Journal of Fisheries and Aquatic Studies; 6(6): 58-60.

\section{How to cite this article:}

Suguna, T. 2020. Survivality and Growth of Fry of Indian Major Carps Reared in Treated Effluents of PSPD, Bhadrachalam. Int.J.Curr.Microbiol.App.Sci. 9(10): 1543-1549.

doi: https://doi.org/10.20546/ijcmas.2020.910.184 